\title{
Developmental biomarkers in schizophrenia and other psychiatric disorders: common origins, different trajectories?
}

\author{
MATCHERI S. KESHAVAN, VAIBHAV DIWADKAR, DAVID R. ROSENBERG
}

\section{BIOMARKERS IN SCHIZOPHRENIA AND OTHER PSYCHIATRIC DISORDERS: COMMON ORIGINS, DIFFERENT TRAJECTORIES?}

The biological bases of illnesses such as schizophrenia and bipolar disorder have been a subject of decades of research. However, the origins of these illnesses are largely unknown. The issue is important and timely because scientific understanding of the origins of these illnesses will permit earlier intervention, leading to better illness management and better outcome.

Understanding neurodevelopment during the adolescent period may be the key to understanding the emergence of psychiatric illness. Adolescence is marked by substantial cortical reorganization and change resulting from continuing processes of myelination and synaptic pruning (Durston et al., 2001; Huttenlocher, 1979). These concurrent processes may be crucial for the development of normal neural networks; myelination accelerates synaptic transfer of information, and normal pruning eliminates redundancies in metabolically expensive cortical gray matter (Keshavan et al., 1994; Laughlin \& Sejnowski, 2003). Developmental changes in neurobiology also depend on patterns of gene- (Lesch, 2004) and behavior-environment interactions (Penn, 2001; Ramakers, 2005). This rapid cortical maturation during adolescence is associated with parallel increases in cognitive proficiency, particularly in basic cognitive systems such as attention and working memory, as well as affect

Address for correspondence: Professor M.S. Keshavan, Wayne State University School of Medicine. Department of Psychiatry, 4201 St. Antoine Blvd. UHC 9B, Detroit, MI 48201 (USA).

Fax: + 1-313-577-5900

E-mail:mkeshava@med.wayne.edu

Declaration of Interest: none relevant. perception and regulation. Pathologic processes including but not restricted to stress, obstetric complications, and alterations in gene expression (Nurnberger \& Foroud, 2000) are likely to impact neurodevelopment and function during this critical period in unpredictable ways. As we discuss below, such pathological processes frequently co-exist across diagnostic boundaries (Walker et al., 2004) though more specific impairments in key neural networks may emerge during the period of adolescence (Pine, 2004).

The recently completed National comorbidity study (Kessler et al., 2005) has shown that about half of Americans meet the criteria for a DSM-IV disorder sometime in their life, with first onset usually in childhood or adolescence, comorbid conditions accruing later in life. Not surprisingly, there has been much debate recently about whether major psychiatric disorders such as schizophrenia and bipolar disorders are distinct clinical entities or whether an expanded psychiatric continuum exists between these disorders. The latter view is supported by co-occurrence of affective and schizophrenic symptoms (Adler \& Strakowski, 2003), evidence of common susceptibility genes for the two disorders (Berrettini, 2003), similarities in neurotransmitter and neurophysiological dysfunction and in treatment response across these disorders (Moller, 2003). Neuroimaging studies show some overlapping findings in these two illnesses, in particular abnormalities in the fronto-striatal circuits that are associated with attention. Thus, attention deficit hyperactivity disorder (ADHD) frequently coexists with schizophrenia (Bellak et al., 1987), OCD (Sukhodolsky et al., 2005) and bipolar disorder (Kim \& Miklowitz, 2002). Many children with ADHD have features of thought disorder similar to children with schizophrenia (Caplan et al., 2002). Individuals at genetic risk for schizophrenia (Keshavan et al., 2002a) and bipolar disorder 
(Chang et al., 2000) also show an increased frequency of attentional impairments. There is also evidence of overlap in other disorders. For example, comorbidities of schizophrenia and Obsessive Compulsive Disorder (OCD) are also frequent (Gross-Isseroff et al., 2003) suggesting some possibility of shared characteristics between them.

Such comorbidity and symptom commonality has made the search for distinct clinical phenotypes of illness expression often elusive. However, they also suggest fundamental commonalities in developmentally mediated dysfunction that may give rise to both common and unique biomarkers associated with these illnesses. Recent neuroimaging and genetic strategies are beginning to clarify biomarkers across childhood/adolescent onset neuropsychiatric disorders. We herein will emphasize the neurodevelopmental bases of diagnostic overlap and symptom commonality. In particular we will address similarities and differences in the neuroanatomical and functional basis of neuropsychiatric disorders that may have their genesis in childhood and development, specifically schizophrenia, attention deficit hyperactivity disorder (ADHD), obsessive compulsive disorder (OCD), and mood disorders including major depressive disorder (MDD) and bipolar disorder (BPD). These disorders are marked by onset in adolescence or early adulthood, and may be preceded or accompanied by symptoms similar to developmental disorders such as ADHD.

\section{COMMON VS. UNIQUE CHANGES IN NEURAL NETWORKS IN PSYCHIATRIC DISORDERS}

Neuroimaging techniques have increasingly elucidated the intrinsic neural circuitry abnormalities underlying the pathophysiology of psychiatric disorders. We herein outline current findings in structural abnormalities inherent to several psychiatric disorders as they relate to schizophrenia in order to highlight the complexities of diagnostic overlap.

Similar to schizophrenia (Sowell et al., 2000), unmedicated children and adolescents with ADHD (Castellanos et al., 2002) have shown reductions in total brain volume. Consistent with reports of decreased prefrontal lobe activity (Andreasen et al., 1992) and decreased striatal volumes (Keshavan et al., 1998; Shihabuddin et al., 1998) in schizophrenia, reduced prefrontal and striatal volumes and hypoactivation of the prefrontal cortex and striatum are seen in ADHD (for a review see Seidman et al., 2005). Decreased levels of N-Acetyl Aspartate (NAA, a measure of neuronal integrity) have also been seen in the striatum in pediatric ADHD (Hesslinger et al. 2001). NAA and gray matter volume reductions in frontal and anterior cingulate cortex are seen in childhood onset schizophrenia patients and unaffected offspring at increased risk for developing schizophrenia (Sowell et al., 2000; Keshavan et al., 1997). Finally, corpus callosum size reductions are seen in ADHD (Hill et al., 2003). similar to those observed in schizophrenia (Shenton et al., 2001); additionally, attentional problems appear to correlate with reductions in corpus callosal size (Kayl et al., 2000).

By contrast with ADHD and schizophrenia, treatmentnaïve pediatric $O C D$ is not characterized by overall brain size reductions (Rosenberg et al., 1997b; Rosenberg \& Keshavan, 1998; Gilbert et al., 2000). Anterior cingulate volume is increased in OCD patients compared to controls (Rosenberg \& Keshavan, 1998; Szeszko et al., 2004) while cingulate volume reductions are seen in schizophrenia (Noga et al., 1995; Takahashi et al., 2003). This observation is consistent with increased error related activation of rostral cingulate cortex in OCD using fMRI (Fitzgerald et al., 2005). Unlike first episode neuroleptic-naïve patients with schizophrenia (Gilbert et al., 2001), pediatric OCD patients show increased thalamic volumes compared to controls. However, similar to ADHD and schizophrenia, reduced striatal volumes are seen in child and adolescent OCD compared to controls in computerized tomography (Luxenberg et al., 1988) and volumetric MRI studies(Rosenberg et al., 1997a). Also, similar to ADHD, reductions in NAA are seen in the striatum in OCD patients compared to controls (Ebert et al., 1997; Bartha et al., 1998).

Total brain size is reduced in MDD in some studies (Steingard et al., 2002; Brambilla et al., 2001) but no significant differences have been observed in this measure between bipolar patients and controls. Thus, reduced total brain volumes may be similar between ADHD and MDD but not OCD and bipolar disorder. Reduced frontal white matter volumes have been reported in adult and pediatric patients with MDD (Steingard et al., 2002). Both ADHD patients and MDD patients have reduced frontal white matter volumes compared to controls (Castellannos et al., 2002), but ADHD patients also have reduced gray matter volumes compared to controls. The subgenual prefrontal cortex volume and cerebral blood flow reductions have been seen in familial adult MDD and BPD patients as compared to non-familial MDD and BPD patients (Drevets, 2000). Increased amygdala volume is consistently observed in volumetric neuroimaging studies of pediatric as well as adult patients with BPD (Frodl et al., 2002; Altshuler et al., 2000; Strakowski et al., 1999). 
fMRI studies show enhanced amygdala activation in response to fearful facial affect in BPD patients (Thomas et al., 2001). Pediatric MDD frequently precedes bipolar disorder in adulthood (Geller et al., 2001; Harrington et al., 1990; Weissman et al., 1999). Thus, increased amygdala and reduced hippocampal volumes are seen in pediatric patients with MDD and first episode adults with MDD (Frodl et al., 2002). These findings contrast reports of decreased amygdala volumes in schizophrenia (see Shenton et al., 2001 for review), and in those at risk for this disorder (Keshavan et al., 2002b). The striatum appears larger in first episode bipolar patients (Strakowski et al., 2002). On the other hand, basal ganglia volumes appear to be reduced in depression (for a review see Soares \& Mann, 1997).

\section{ETIOLOGICAL COMMONALITIES AND DIFFERENCES ACROSS DISORDERS}

There is a substantial genetic component to both schizophrenia and ADHD. Alterations in the gene encoding the dopamine D4 receptor have been reported in children with ADHD (LaHoste et al., 1996; Benjamin et al., 1996; Ebstein et al., 1996). An association between alterations in the gene encoding the dopamine transporter and ADHD has also been reported (Cook et al., 1995; Gill et al., 1997). Association with polymorphisms of the catechol-O-methyltransferase (COMT) gene which encodes an enzyme that degrades dopamine, has been reported in schizophrenia (Sawa \& Snyder, 2002) as well as in BPD (Badner \& Gershon, 2002). Targeted deletions of the COMT gene appears to decrease levels of dopamine only in the prefrontal cortex (Gogos et al., 1998). Prefrontal dopaminergic deficits have been thought to underlie attentional and executive function deficits seen in both schizophrenia and BPD.

By contrast with schizophrenia where replicable findings are beginning to emerge (O'Donovan et al., 2003), relatively few replicated genetic susceptibility loci have been identified for OCD and BPD. However, recent studies have suggested that there may be some susceptibility genes that are common to both schizophrenia; these include Neuregulin l (NRG1) gene (Green et al., 2005), COMT and BDNF (Maier et al., 2005). Also of interest is the modest association observed between serotonin transporter gene and affective disorder (Lasky-Su et al., 2005). Recent fMRI studies have suggested that this association may be mediated by the effects of this gene on the response bias of the human amygdalae to environmental threat (Hariri et al., 2005). Interestingly, a modest but significant association between this gene polymorphisms and affective disorders has been noted by metaanalyses (Lasky-Su et al., 2005).

While obstetric complications (OCs) are known to contribute to the vulnerability for schizophrenia, the diagnostic specificity and the cause effect relationship remain unclear; OCs are more frequent in other severe psychiatric disorders, such as ADHD (SprichBuckminster et al., 1993; Milberger et al., 1997). OCs may interact with genetic liability and later environmental risk factors (Verdoux \& Sutter, 2002). OCs have been observed inconsistently in BPD (reviewed in Buka \& Fan, 1999). Overall, the risk-enhancing effect of OCs has been better established in schizophrenia by comparison with bipolar disorder (Murray et al., 2004). OCs may contribute to volume losses in medial temporal structures such as amygdala, though genetic risk also contributes to this (Keshavan et al., 2002b).

\section{TOWARD A SYNTHESIS}

The observed pathophysiological similarities across psychiatric disorders are consistent with the observations of frequent comorbidity and diagnostic overlap discussed earlier. The similar reductions in ADHD and schizophrenia in overall brain volume, corpus callosum and frontostriatal circuits is consistent with evidence of attentional impairment as a core feature of schizophrenia as well as with observations of attentional problems being among the most robust premorbid predictors of later schizophrenia. Attentional impairment also predicts the later emergence of BPD (Kim \& Miklowitz, 2002). Interestingly, an association has also been proposed between ADHD and childhood OCD (Geller et al., 2002). Thus, attentional impairments in childhood, perhaps related to frontostriatal pathology, may represent a common and nonspecific precursor for diverse psychiatric presentations in adulthood such as OCD, BPD and schizophrenia. There are also some intriguing differences. Overall brain size reductions, seen in schizophrenia, are less prominent in BPD and OCD. Further, OCD patients, unlike schizophrenia patients, show increased and not decreased cingulate volumes. Similarly, BPD and depressive patients show larger amygdala volumes in contrast to the smaller amygdala volume observed in schizophrenia. BPD patients may also show larger basal ganglia unlike the schizophrenia patients. How do we make sense of these similarities and differences?

First, differential severity and trajectories of neurobiological disruptions may calse the varied phenotypic 
expressions of psychiatric illnesses and disorders such as schizophrenia, bipolar disorder and obsessive compulsive disorder. Massive disruptions in circuitry may lead to extreme deficits in cognition and thought disorder that are observed in illnesses like schizophrenia (Lawrie et al., 2002). On the other hand, more selective disruptions in frontal, sub-genual and limbic circuitry may underlie disorders of mood regulation such as observed in disorders of mood like bipolar disorder and depression (Drevets. 1999). Selective disruptions in frontal-striatal circuitry may lead to patterns of impaired inhibition that is observed in disorders such as obsessive-compulsive disorder (Maltby et al., 2005). Second, some of the differences in phenotypic manifestations may result from the consequences of continued illness, perhaps emerging from progressive neurodeteriorative processes at least in some disorders such as schizophrenia (Keshavan, 1999). Finally, these distinct developmental trajectories may be related to differential compensatory pathoplastic responses of the subcortical brain structures such as the cingulate and amygdala and may mediate the emergence of distinct symptomatic presentations. It is well known that the amygdala and the cingulate, respectively, are critically involved in affect regulation and conflict monitoring (Ledoux, 2003). Thus, the amygdala enlargements in BPD might represent a pathological hyperplasia in that region related to repeated activation in the context of highly valenced emotional states, such as the manic and depressive episodes. Likewise, the cingulate enlargement in OCD might reflect a hyper-responsive error-monitoring system. On the other hand, the failure of optimal functioning of cingulate may underlie the deficits in selfmonitoring leading to disorganized thinking in schizophrenia. Additionally, interactions between genetic predisposition and OCs such as hypoxia may result in smaller volumes of the amygdala and hippocampus, leading to diminished affective responsivity and blunted affect. The similarities and unique differences in pathophysiological trajectories may stem from differential combinations of genetic factors and environmental influences in each individual.

An integrated approach to longitudinal follow-up studies of children at risk for a variety of major psychiatric disorders using the non-invasive neuroimaging techniques can help us test such predictions. First, such studies enable us to further clarify the common and distinct neurodevelopmental alterations across diverse disorders and help us unravel the shared and distinct vulnerability factors of genetic or environmental origin. It would also help us understand whether changes in brain biology are related to the causes of, consequences of, or compensato- ry responses to these illnesses. Second, mapping the developmental trajectories of adult psychiatric disorders can help in designing prevention strategies. Of concern are recent observations that treatment is significantly delayed in such childhood disorders, leading to considerable cumulative morbidity (Kessler et al., 2005). Improved knowledge of the common developmental basis of psychiatric disorders will clearly promote a lifecourse developmental approach to psychopathology and eventually improve treatment and prevention. Emerging research suggests that apparently distinct clinical phenotypes associated with neuropsychiatric illness may have common origins in developmental derailment. The future to better understanding of psychiatric illnesses may involve understanding the trajectories and timing of developmental derailments and the relationship between these trajectories and the adopted classification of different disorders.

Acknowledgments. This work was supported in part by NIMH grants K02 01180 and MH 64023 (MSK).

\section{REFERENCES}

Adler C.M. \& Strakowski S.M. (2003) Boundaries of schizophrenia. Psychiatric Clinics of North America 26, 1-23.

Altshuler L.L.. Bartzokis G., Grieder T., Curran J., Jimenez T.. Leight K.. Wilkins J., Gerner R. \& Mintz J. (2000). An MRI study of temporal lobe structures in men with bipolar disorder or schizophrenia Biological Psychiatry 48, 147-162.

Andreasen N.C.. Rezai K., Alliger R., Swayze V.W. 2nd, Flaum M. Kirchner P., Cohen G. \& O'Leary D.S. (1992). Hypofrontality in neuroleptic-naive patients and in patients with chronic schizophrenia. Assessment with xenon 133 single-photon emission computed tomography and the Tower of London. Archives of General Psychiatry 49, 943-958.

Badner J.A. \& Gershon E.S. (2002). Meta-analysis of whole-genome scans of bipolar disorder and schizophrenia. Molecular Psychiary 7. 405-411.

Bartha R., Stein M.B., Williamson P.C., Drost D.J., Neufeld R.W., Carr T.J., Canaran G., Densmore M., Anderson G. \& Siddiqui A.R. (1998). A short echo lH spectroscopy and volumetric MRI study of the corpus striatum in patients with obsessive compulsive disorder and comparison subjects. American Joumal of Psichiatry 155. 1584-1591

Bellak L., Kay S.R. \& Opler L.A. (1987). Attention deficit disorder psychosis as a diagnostic category. Psychiatric Developments 5, 239263.

Benjamin J.. Li L., Patterson C., Greenberg B.D., Murphy D.L. \& Hamer D.H. (1996). Population and familial association between the D4 dopamine receptor gene and measures of Novelty Seeking. Nature Genetics 12, 81-84.

Berrettini W. (2003). Evidence for shared susceptibility in bipolar disorder and schizophrenia. American Joumal of Medical Genetics Part C: Seminars in Medical Genetics 123(1), 59-64.

Brambilla P.. Harenski K.. Nicoletti M.A.. Mallinger A.G.. Frank E. Kupfer D.J.. Keshavan M.S. \& Soares J.C. (2001). Anatomical MRI study of basal ganglia in bipolar disorder patients. Psychiatry Research 106, 65-80. 
Buka S. \& Fan A. (1999). Association of prenatal and perinatal complications with subsequent bipolar disorder and schizophrenia. Schisophrenia Research 39.113-119.

Caplan R., Guthrie D.. Tang B.. Nuechterlein K.H. \& Asarnow R.E. (2002). Thought disorder in attention-deficit hyperactivity disorder. International Review Neurobiology 49. 269-284.

Castellanos F.X., Lee P.P., Sharp W.. Jeffries N.O.. Greenstein D.K.. Clasen L.S.. Blumenthal J.D.. James R.S.. Ebens C.L.. Walter J.M.. Zijdenbos A., Evans A.C.. Giedd J.N. \& Rapoport J.L. (2002). Developmental trajectories of brain volume abnormalities in children and adolescents with attention-deficit/hyperactivity disorder. Joumal of the American Medical Association 288. 1740-1748.

Chang K.D. Steiner H. \& Ketter TA. (2000). Psychiatric phenomenology of child and adolescent bipolar offspring. Joumal of the American Academy of Child and Adolescem Psychiatry 39. 453460.

Cook E.H.. Sterin M.A.. Krasowski M.D.. Cox N.J.. Olkon D.M., Kieffer J.E. \& Leventhal B.L. (1995). Association of attentiondeficit disorder and the dopamine transporter gene. American Journal of Human Genetics 56. 993-998.

Drevets W.C. (1999). Prefrontal cortical-amygdalar metabolism in major depression. Amnals of the New York Academy of Sciences 877. 614-637.

Drevets W.C. (2000). Neuroimaging studies of mood disorders. Biological Psichiatry 48, 813-829.

Durston S.. Hulshoff Pol H.E., Casey B.J., Giedd J.N., Buitelaar J.K. \& van Engeland H. (2001). Anatomical MRI of the developing human brain: What have we learned? Journal of the American Academy of Child and Adolescent Psichiatry 40, 1012-1020.

Ebert D., Speck O., Konig A., Berger M.. Hennig J. \& Hohagen F. (1997). 1H-magnetic resonance spectroscopy in obsessive-compulsive disorder: Evidence for neuronal loss in the cingulate gyrus and the right striatum. Psychiarn Research 74, 173-176.

Ebstein R.P., Novick O., Umansky R., Priel B., Osher Y., Blaine D.. Bennet E.R., Nemanov L., Katz M. \& Belmaker R.H. (1996). Dopamine D4 receptor (D4DR) exon III polymorphism associated with the human personality trait of Novelty Seeking. Nature Genetics 12.78-80.

Fitzgerald K.D., Welsh R.C., Gehring W.J., Abelson J.L., Himle J.A., Liberzon I. \& Taylor S.F. (2005) Error-related hyperactivity of the anterior cingulate cortex in obsessive-compulsive disorder. Biological Psychiatry 57(3), 287-294.

Frodl T.. Meisenzahl E., Zetzsche T., Bottlender R., Born C., Groll C.. Jager M.. Leinsinger G., Hahn K. \& Moller H.J. (2002) Enlargement of the amygdala in patients with a first episode of major depression. Biological Psychiatry 51, 708-714.

Geller D.A., Biederman J., Faraone S.V.. Cradock K., Hagermoser L.. Zaman N.. Frazier J.A.. Coffey B.J. \& Spencer T.J. (2002). Attention-deficithyperactivity disorder in children and adolescents with obsessive-compulsive disorder: fact or artifact? Joumal of the American Academy of Child and Adolescent Psychiatry 41, 52-58.

Geller B., Zimerman B., Williams M., Bolhofner K. \& Craney J.L. (2001). Bipolar disorder at prospective follow-up of adults who had prepubertal major depressive disorder. American Journal of Psychiatry 158, 125-127.

Gilbert A.R.. Moore G.J.. Keshavan M.S., Paulson L.A., Narula V.. Mac Master F.P., Stewart C.M. \& Rosenberg D.R. (2000). Decrease in thalamic volumes of pediatric patients with obsessive-compulsive disorder who are taking paroxetine. Archives of General Psychiary 57, 449-456.

Gilbert A.R., Rosenberg D.R., Harenski K.. Spencer S., Sweeney J.A. \& Keshavan M.S. (2001). Thalamic volumes in patients with firstepisode schizophrenia. American Journal of Psychiatry 158(4), 618 624.

Gill M.. Daly G., Heron S.. Hawi Z. \& Fizgerald M. (1997). Confirmation of association between attention deficit hyperactivity disorder and a dopamine transporter polymorphism. Biological Psychiatry 2. 311-313.
Gogos J.A.. Morgan M.. Luine V.. Santha M.. Ogawa S., Pfaff D. \& Karayiorgou M. (1998). Catechol-O-methyltransferase-deficient mice exhibit sexually dimorphic changes in catecholamine levels and behavior. Proceedings of the National Academy of Sciences of the United States of America US 95, 9991-9996.

Green E.K., Raybould R.. Macgregor S.. Gordon-Smith K., Heron J., Hyde S.. Grozeva D.. Hamshere M. Williams N.. Owen M.J.. O'Donovan M.C.. Jones L.. Jones I.. Kirov G. \& Craddock N. (2005). Operation of the schizophrenia susceptibility gene. neuregulin 1 . across traditional diagnostic boundaries to increase risk for bipolar disorder. Archives of General Psychiarry 62(6), 642-648.

Gross-Isseroff R., Hermesh H., Zohar J. \& Weizman A. (2003). Neuroimaging communality between schizophrenia and obsessive compulsive disorder: a putative basis for schizo-obsessive disorder? World Journal of Biological Psychiatry 4, 129-134.

Hariri A.R.. Drabant E.M., Munoz K.E., Kolachana B.S.. Mattay V.S., Egan M.F. \& Weinberger D.R. (2005) A susceptibility gene for affective disorders and the response of the human amygdala. Archives of General Psychiatry 62(2), 146-152.

Harrington R., Fudge H., Rutter M., Pickles A, \& Hill J. (1990). Adult outcomes of childhood and adolescent depression: Psychiatric status. Archives of General Psychiatry. 47, 465-473.

Hesslinger B., Thiel T., Tebartz van Elst L., Hennig J. \& Ebert D. (2001). Attention-deficit disorder in adults with or without hyperactivity: Where is the difference? A study in humans using short echo (1) H-magnetic resonance spectroscopy. Neuroscience Letters 304, 117-119.

Hill D.E., Yeo R.A., Campbell R.A., Hart B., Vigil J. \& Brooks W. (2003). Magnetic resonance imaging correlates of attentiondeficit/hyperactivity disorder in children. Neuropsychology 17, 496506.

Huttenlocher P.R. (1979). Synaptic density in human frontal cortex Developmental changes and effects of aging. Brain Research 163 . 195.

Kayl A.E., Moore B.D. 3rd, Slopis J.M., Jackson E.F. \& Leeds N.E. (2000). Quantitative morphology of the corpus callosum in children with neurofibromatosis and attention-deficit hyperactivity disorder. Journal of Child Neurology 15, 90-96.

Keshavan M.S. (1999). Development, disease and degeneration in schizophrenia: a unitary pathophysiological model. Journal of Psychiatric Research 33(6), 513-521.

Keshavan M.S., Anderson S. \& Pettegrew J.W. (1994) Is schizophrenia due to excessive synaptic pruning in the prefrontal cortex? Joumal of Psychiatric Research 28, 239-265.

Keshavan M.S., Montrose D.M., Pierri J.N., Dick E.L., Rosenberg D., Talagala L. \& Sweeney J.A. (1997). Magnetic resonance imaging and spectroscopy in offspring at risk for schizophrenia: preliminary studies. Progress in Neuropsychopharmacology and Biological Psychiatry 21, 1285-1295.

Keshavan M.S., Rosenberg D., Sweeney J.A. \& Pettegrew J.W. (1998) Decreased caudate volume in neuroleptic-naive psychotic patients. American Journal of Psychiatry 155, 774-778.

Keshavan M.S., Sujata M., Mehra A., Montrose D.M. \& Sweeney J.A (2002a). Psychosis proneness and ADHD in young relatives at risk for schizophrenia. Schizophrenia Research 59, 85-92.

Keshavan M.S.. Dick E., Mankowski I., Harenski K.. Montrose D.M., Diwadkar V. \& DeBellis M. (2002b). Decreased left amygdala and hippocampal volumes in young offspring at risk for schizophrenia. Schizophrenia Research 58. 173-183.

Kessler R.C., Berglund P.. Demler O., Jin R.. Merikangas K.R. \& Walters E.E. (2005). Lifetime prevalence and age-of-onset distributions of DSM-IV disorders in the National Comorbidity Survey Replication. Archives of General Psychiatn Jun;62(6), 593-602. Erratum in: Archives of General Psychiatry 62(7). 768.

Kim E.Y. \& Miklowitz D.J. (2002). Childhood mania, attention deficit hyperactivity disorder and conduct disorder: A critical review of diagnostic dilemmas. Bipolar Disorder 4, 215-225.

LaHoste G.J.. Swanson J.M., Wigal S.B.. Glabe C.. Wigal T.. King N. 
\& Kennedy J.L. (1996). Dopamine D+ receptor gene polymorphism is associated with attention-deficit hyperactivity disorder. Molecular Psychiatr. 1. 121-124.

Lasky-Su J.A.. Faraone S.V.. Glatt S.J. \& Tsuang M.T. (2005). Metaanalysis of the association between two polymorphisms in the serotonin transporter gene and affective disorders. American Joumal of Medical Genetics. Part B. Neuropsychiatric Genetics 133(1). 110115.

Laughlin S.B. \& Sejnowski T.J. (2003). Communication in neuronal networks. Science 301(56+1). 1870-1874

Lawrie S.M. Buechel C.. Whalley H.C.. Frith C.D.. Friston K.J. \& Johnstone E.C. (2002). Reduced frontotemporal functional connectivity in schizophrenia associated with auditory hallucinations. Biological Psychiatr 51(12). 1008-1011.

Ledoux J. (2003). The emotional brain. fear. and the amygdala. Cellutar and Molecular Neurobiology 23.727-738.

Lesch K.P. (2004). Gene-environment interaction and the genetics of depression. Jounal of Psychiarn and Neuroscience 29(3), 174-184.

Luxenberg J.S.. Swedo S.E., Flament M.F.. Friedland R.P.. Rapoport J. \& Rapoport S.I. (1988). Neuroanatomical abnormalities in obsessive-compulsive disorder detected with quantitative $X$-ray computed tomography. American Joumal of Psychiatry 145, 1089-1093.

Maier W.. Hofgen B.. Zobel A. \& Rietschel M. (2005). Genetic models of schizophrenia and bipolar disorder Overlapping inheritance or discrete genotypes? European Archives of Psychiatry and Clinical Neuroscience 255(3), 159-166.

Maltby N.. Tolin D.F., Worhunsky P.. O'Keefe T.M. \& Kieht K.A. (2005). Dysfunctional action monitoring hyperactivates frontal-striatal circuits in obsessive-compulsive disorder: an event-related fMRI study. Neurolmage 24(2), 495-503.

Milberger S., Biederman J., Faraone S.X., Guite J. \& Tsuang M.T. (1997). Pregnancy, delivery, and infancy complications and attention deficit hyperactivity disorder: issues of gene-environment interaction. Biological Psychiatry 41, 65-75.

Moller H.J. (2003). Bipolar disorder and schizophrenia: distinct illnesses or a continuum? Joumal of Clinical Psychiatry 64, 23-27.

Murray R.M., Sham P.. Van Os J., Zanelli J., Cannon M. \& McDonald C. (2004). A developmental model for similarities and dissimilarities between schizophrenia and bipolar disorder. Schizophrenia Research 7I(2-3), 405-416.

Noga J.T., Aylward E., Barta P.E. \& Pearlson G.D. (1995). Cingulate gyrus in schizophrenic patients and normal volunteers. Psychiatr. Research 61, 201-208.

Nurnberger J.I. Jr. \& T. Foroud (2000). Genetics of bipolar affective disorder. Current Psychiatry Reports 2(2), 147-157.

O'Donovan M.C.. Williams N.M. \& Owen M.J. (2003) Recent advances in the genetics of schizophrenia. Human Molecular Genetics 12. Suppl 2. R125-133.

Penn A.A. (2001), Early brain wiring: activity-dependent processes. Schizophremia Bulletin 27(3), 337-347.

Pine D.S. (2004). Integrating research on developmental psychopathology and neuroscience in the study of adolescence: introduction to part II. Annals of the New York Academy of Sciences 1021, 61-63.

Ramakers G.J. (2005). Neuronal network formation in human cerebral cortex. Progress in Brain Research 147, 1-14.

Rosenberg D.R, Keshavan M.S.. O'Hearn K.M.. Dick E.L.. Bagwell W.W., Seymour A.B.. Montrose D.M.. Pierri J.N. \& Birmaher B. (1997a). Frontostriatal measurement in treatment-naïve children with obsessive-compulsive disorder. Archives of General Psychiatry $54,824-830$

Rosenberg D.R., Keshavan M.S., Dick E.L.. Bagwell W.W., MacMaster F.P. \& Birmaher B. (1997b). Corpus callosal morphology in treatment-naive pediatric obsessive compulsive disorder. Progress in Neuropsychophamacology and Biological Psychiary. 21. 1269-1283.

Rosenberg D.R. \& Keshavan M.S. (1998). A.E. Bennett Research Award. Toward a neurodevelopmental model of obsessive-compulsive disorder. Biological Psychiarry 43. 623-640.
Sawa A. \& Snyder S. (2002). Schizophrenia: Diverse approaches to a complex disease. Science 296, 692-695.

Shenton M.E. Dickey C.C.. Frumin M. \& McCarley R.W. (2001). A review of MRI findings in schizophrenia. Schizophrenia Research 15. $49(1-2) .1-52$

Shihabuddin L., Buchsbaum M.S., Hazlett E.A., Haznedar M.M. Harvey P.D.. Newman A.. Schnur D.B.. Spiegel-Cohen J.. Wei T., Machac J.. Knesaurek K.. Vallabhajosula S.. Biren M.A.. Ciaravolo T.M. \& Luu-Hsia C. (1998). Dorsal striatal size, shape, and metabolic rate in never-medicated and previously medicated schizophrenics performing a verbal learning task. Archives of General Pstchiatry 55, 235-243.

Seidman L.J.. Valera F.M. \& Makris N. (2005). Structural brain imaging of attention-deficit/hyperactivity disorder. Biological Psychiatry 27( (11). 1263-1272.

Soares J.C. \& Mann J.J. (1997). The anatony of mood disorders-review of structural neuroimaging studies. Biological Psychiary 41, 86106.

Sowell E.R.. Toga A.W. \& Asarnow R. (2000). Brain abnormalities observed in childhood-onset schizophrenia: A review of the structural magnetic resonance imaging literature. Mental Retardation and Developmental Disabilities Research Reviens 6, 180-185.

Sprich-Buckminster S.. Biederman J., Milberger S.. Faraone S.W. \& Lehman B.K. (1993). Are perinatal complications relevant to the manifestation of ADD? Issues of comorbidity and familiality. Joumal of the American Academy of Child and Adolescent Psychiatry 32. 1032-1037.

Steingard R.J., Renshaw P.F., Hennen J., Lenox M., Cintron C.B. Young A.D., Connor D.F., Au T.H. \& Yurgelun-Todd D.A. (2002). Smaller frontal lobe white matter volumes in depressed adolescents. Biological Psychiatry 52, 413-417.

Strakowski S.M., DelBeilo M.P., Sax K.W., Zimmerman M.E., Shear P.K., Hawkins J.M. \& Larson E.R. (1999). Brain magnetic resonance imaging of structural abnormalities in bipolar disorder. Archives of General Psichiatry 56, 254-260.

Strakowski S.M., DelBello M.P., Zimmerman M.E., Getz G.E., Mills N.P., Ret J., Shear P. \& Adler C.M. (2002). Ventricular and periventricular structural volumes in first- versus multiple-episode bipolar disorder. American Joumal of Psychiatry 159. 1841-1847.

Sukhodolsky D.G., do Rosario-Campos M.C., Scahill L., Katsovich L., Pauls D.L., Peterson B.S., King R.A., Lombroso P.J., Findley D.B. \& Leckman J.F. (2005). Adaptive, emotional, and family functioning of children with obsessive-compulsive disorder and comorbid attention deficit hyperactivity disorder. American Journal of Psychiatry 162(6), 1125-1132.

Szeszko P.R., MacMillan S., McMeniman M., Chen S, Baribault K. Lim K.O.. Ivey J., Rose M., Banerjee S.P., Bhandari R., Moore G.J. \& Rosenberg D.R. (2004). Brain structural abnormalities in psychotropic drug-naive pediatric patients with obsessive-compulsive disorder. American Joumal of Psychiatry 161(6), 1049-1056.

Takahashi T.. Suzuki M., Kawasaki Y., Hagino H., Yamashita I., Nohara S.. Nakamura K., Seto H. \& Kurachi M. (2003). Perigenual cingulate gyrus volume in patients with schizophrenia: a magnetic resonance imaging study. Biological Psychiatry 53, 593-600.

Thomas K.M. Drevets W.C.. Dahl R.E., Ryan N.D., Birmaher B. Eccard C.H., Axelson D., Whalen P.J. \& Casey B.J. (2001). Amygdala response to fearful faces in anxious and depressed children. Archives of General Psichiatry 58, 1057-1063.

Verdoux H. \& Sutter A.L. (2002). Perinatal risk factors for schizophrenia: diagnostic specificity and relationships with maternal psychopathology. American Journal of Medical Genetics 114, 898-905.

Walker E.F., Sabuwalla Z. \& Huot R. (2004). Pubertal neuromaturation, stress sensitivity, and psychopathology. Development and Psichopathology 16(4), 807-824.

Weissman M.M.. Wolk S.. Wickramaratne P.. Goldstein R.B., Adams P.. Greenwald S.. Ryan N.D.. Dahl R.E. \& Steinberg D. (1999). Children with prepubertal-onset major depressive disorder and anx iety grown up. Archives of General Psychiatry 56. 794-801. 